\title{
Neurobehavioural Mechanism of Antidepressant Effect of Methanol Stem Bark Extract of Adansonia digitata (Linn) in Tail Suspension Test in Mice
}

\author{
Akinpelu Lateef Abiola ${ }^{1, *}$, Adebayo Muritala Ayofe ${ }^{2}$, Adesola Adedoyin ${ }^{1}$ \\ ${ }^{1}$ Department of Pharmacology and Toxicology, Dora Akunyili College of Pharmacy, Igbinedion University, Nigeria \\ ${ }^{2}$ Department of Pharmacognosy, Dora Akunyili College of Pharmacy, Igbinedion University, Nigeria
}

Copyright $\odot 2019$ by authors, all rights reserved. Authors agree that this article remains permanently open access under the terms of the Creative Commons Attribution License 4.0 International License

\begin{abstract}
Aim: An earlier study has demonstrated the in-vivo antidepressant effect of methanol stem bark extract of Adansonia digitata, using soxhlet extraction protocol, but there is a lack of scientific data on its neurobehavioural mechanism of action. This study, therefore, investigated its antidepressant potentials, using cold maceration method, and determined the probable neurobehavioural mechanism of its antidepressant-like effect. Methodology: The antidepressant-like effect of the extract was evaluated in tail suspension test, at graded doses in mice. Subsequently, the probable neurobehavioural mechanism of the antidepressant-like effect of the extract was investigated by intraperitoneal pretreatment with adrenergic, serotonergic, dopaminergic, and muscarinic cholinergic receptor antagonists; GABA agonist; nitric oxide precursor and inhibitors; and using a putative neuromodulator at NMDA receptors prior to the extract administration. Results and discussion: The extract at all the doses used, significantly $(\mathrm{p}<0.05)$ and dose-dependently decreased the immobility time in tail suspension test without significant $(p>0.05)$ alteration on locomotor behaviour in mice. However, the anti-immobility potential of the extract was significantly $(\mathrm{p}<0.05)$ reversed by prazosin, yohimbine, sulpiride, methylene blue, L-arginine and baclofen, suggesting the involvement of adrenergic, dopaminergic, GABAerargic and nitergic pathways. Conclusion: This study, therefore, concluded that the extract may possess antidepressant effect and its mechanism may involve multiple pathways.
\end{abstract}

Keywords Adansonia digitata, Cold Maceration, Antidepressant, Neurobehavioural Mechanism, Multiple Receptor Pathways

\section{Introduction}

According to The World Health Organization, depression is among the top ten causes of morbidity, and mortality world over [1], and it is envisaged to be the leading cause of morbidity and mortality by the year 2030 $[2,3]$. Patients with depression have symptoms that reflect a functional deficit in brain monoamine neurotransmitters, specifically norepinephrine, serotonergic [4] and dopaminergic systems [5]. Other neurotransmitters such as GABA acting via $\mathrm{GABA}_{\mathrm{B}}$ receptor [6], $\beta$ adrenoceptors [7], muscarinic cholinergic receptor [8], glutaminergic via NMDA receptor [9], and nitric oxide signaling pathways [8] have been implicated in depression.

Despite the availability of synthetic antidepressant drugs, depression remains a major medical problem [10]. This is because the currently available antidepressant drugs are associated with a numerous side effect which includes weight gain, hypopiesia, sexual dysfunction, and cardiac toxicity and sleep disorder $[11,12,13]$. Therefore, herbal therapies should be considered alternative or complementary medicines [14]. Among the demonstrated herbal therapies effective for the treatment of depression are Hypericum perforatum L. [15], Cordyceps sinensis [16], and Perilla frutescens [17].

Adansonia digitata L. (Bombacaceae), otherwise called baobab, is a large iconic tree indigenous to Africa, where it is found in many African countries [18]. The African species Adansonia digitata is indigenous to, and widely distributed throughout the savannas and savanna woodlands of sub-Saharan Africa [19].

Numerous ethnomedicinal values are attributed to the various plant parts of Adansonia digitata [18]. For example, stem bark is used in the treatment of neuropsychiatric disorder [20], depression [21], malaria [19], wound healing [22], among other indications in Africa traditional medicine and have been evaluated as a substitute for imported western drugs [23, 24].

The different parts of Adansonia digitata have numerous biological properties including antimicrobial, antiviral [25], antioxidant [26], hepatoprotective [27], anti-inflammatory, 
analgesic and antipyretic activities [24].

According to the World Health Organisation, depression will be the second leading cause of disability in the developed countries in 2020 [28], and the continuous use of the currently available synthetic antidepressant drugs acting via multiple neurotransmitters system [29], have been associated with some severe side effects [30]. Therefore, a continuous search for new affordable therapeutic agents with minimal side effects from medicinal plants is imperative. Although the antidepressant effect of Adansonia digitata stem bark has been demonstrated using hot extraction protocol on forced swimming (FST) and tail suspension (TST) tests [21], but there is lack of scientific data on its probable neurobehavioural mechanism of action, therefore, the objective of this study was to investigate the antidepressant effect of the stem bark extract using cold extraction protocol, as well as determine its neurobehavioural mechanism of action in TST.

\section{Materials and Methods}

Adansonia digitata stem bark was collected in Bode Osi in Ola Oluwa Local Govt area of Osun State. It was authenticated by Mr. G. A. Ademoriyo of the Herbarium Unit, Department of Botany, Faculty of Science, OAU, Ile-Ife and herbarium voucher Ife 17705 was obtained and herbarium specimen deposited.

\subsection{Preparation of Plant Materials}

Adansonia digitata stem barks were air dried at room temperature. The dried stem barks were pulverized, and $300 \mathrm{~g}$ of the powdered material, was extracted with 1.5 litres of eighty percent (80\%) methanol for $72 \mathrm{~h}$. The filtrate was then concentrated in vacuo at a temperature of $40^{\circ} \mathrm{C}$ and further freeze-dried to yield $2.3 \mathrm{~g}(0.77 \%)$ crude extract and coded MSAD.

\subsection{Drugs}

Prazosin hydrochloride, cyproheptadine hydrochloride, yohimbine hydrochloride, fluoxetine hydrochloride, propranolol hydrochloride, baclofen, $( \pm)$ sulpiride, atropine sulphate, L-arginine, L-NG-Nitroarginine, methylene blue and ascorbic acid were all from Sigma Aldrich, St. Louis, MO, USA; and normal saline (Unique Pharmaceutical Limited, Lagos, Nigeria). MSAD and other drugs were dissolved in normal saline and freshly prepared on each day of the experiment.

\subsection{Animals}

Male adult albino mice weighing $18-25 \mathrm{~g}$ were obtained from the Animal House, Igbinedion University, Okada, Edo State, Nigeria. The animals were fed with a standard commercial diet (Guinea feeds brand, Bendel Feeds Nigeria) and water ad libitum. The animals were acclimatized to the laboratory condition for at least one week before the commencement of the behavioural experiments. The experimental procedures employed in this study are in accordance with the approved institutional guidelines and within the confine of internationally accepted principles for Laboratory Animal Use and Care (EEC Directive of 1986; 86/609/EEC) [31]. All efforts were made to reduce animal sufferings and to use the minimum number of animals in this study.

\subsection{Acute Toxicity Test}

\section{Acute Oral Toxicity Study}

The acute oral toxicity test of MSAD was conducted according to the Organization for Economic Cooperation and Development (OECD) guidelines 425 of 2008. The experimental procedures were carried out in two phases. In the first phase, a single female mouse was orally administered $2000 \mathrm{mg} / \mathrm{kg}$ of MSAD after $3 \mathrm{~h}$ of fasting. The mouse was observed for any signs of acute behavioural toxicity within the first $24 \mathrm{~h}$. Based on the outcome of the first phase; another 4 female mice were orally administered the same dose of MSAD and subsequently observed for any sign of delayed toxicity or death in the next 14 days [32]. Based on the outcome of the experiment, the two phases of the experiments were repeated for $5000 \mathrm{mg} / \mathrm{kg}$.

\subsection{Pharmacological Experiments}

\section{Effect of MSAD in Tail Suspension Test (TST)}

The TST employed for screening the potential antidepressants effect of MSAD was carried out as previously done elsewhere [33]. Mice were randomly divided into 5 groups, containing 5 mice per group $(n=5)$. Group I (Vehicle): mice received normal saline p.o (10 $\mathrm{mL} / \mathrm{kg}$ ); Groups II-IV (Treatment groups): mice received 200, 400 and $800 \mathrm{mg} / \mathrm{kg}$, p.o of MSAD, and Group V (received the reference drug): mice received fluoxetine (20 $\mathrm{mg} / \mathrm{kg}$, i.p.). One hour after oral ingestion of MSAD and 30 min after intraperitoneal injection of fluoxetine, each mouse was suspended on the edge of a table, $50 \mathrm{~cm}$ above the floor with the help of adhesive tape placed approximately $1 \mathrm{~cm}$ from the tip of the tail. Immobility duration was recorded for the last 4 minutes during 6 minutes period in different groups. The mouse animal was considered immobile, when it did not show any movement of the body, and hanged passively.

\subsection{Mechanism of Action of MSAD in TST}

Involvement of Noradrenergic Pathway

Mice were randomly divided into 5 groups containing 5 mice per group $(\mathrm{n}=5)$. Group I: mice in this group received normal saline p.o $(10 \mathrm{~mL} / \mathrm{kg})$; Groups II: mice received 
$200 \mathrm{mg} / \mathrm{kg}$, p.o of MSAD; Group III-V: mice were pretreated with prazosin $\left(62.5 \mu \mathrm{g} / \mathrm{kg}\right.$, an $\alpha_{1}$ adrenoceptor antagonist), yohimbine $\left(1 \mathrm{mg} / \mathrm{kg}, \quad \alpha_{2}\right.$ adrenoceptor antagonist), propranolol ( $2 \mathrm{mg} / \mathrm{kg}, \beta$-receptor antagonist), $30 \mathrm{~min}$ before the administration of MSAD $(200 \mathrm{mg} / \mathrm{kg}$, p.o.) respectively. One hour after normal saline and extract administration in Group I and II and 30 min after oral ingestion of MSAD in Group III-V, the mice were submitted for TST [7].

\section{Involvement of Serotonergic Pathway}

Mice were randomly divided into 3 groups, containing 5 mice per group $(\mathrm{n}=5)$. Group I: mice in this group received normal saline p.o $(10 \mathrm{~mL} / \mathrm{kg})$; Groups II: mice received $200 \mathrm{mg} / \mathrm{kg}$, p.o of MSAD; Group III: mice were pretreated with cyproheptadine $(3 \mathrm{mg} / \mathrm{kg}$, i.p., a 5-HT receptor antagonist), and 15 min later they received MSAD (200 $\mathrm{mg} / \mathrm{kg}$, p.o.). One hour after oral administration of normal saline or extract in Groups I-III, mice were evaluated on TST as previously described [34].

\section{Involvement of Dopaminergic Pathway}

Mice were randomly divided into 3 groups, containing 5 mice per group $(n=5)$. Group I: mice received normal saline p.o $(10 \mathrm{~mL} / \mathrm{kg})$; Groups II: mice received $200 \mathrm{mg} / \mathrm{kg}$, p.o of MSAD; Group III: mice were pretreated with sulpiride $\left(50 \mathrm{mg} / \mathrm{kg}\right.$, i.p., a selective dopamine $\mathrm{D}_{2}$ receptor antagonist), $30 \mathrm{~min}$ before administration of MSAD (200 $\mathrm{mg} / \mathrm{kg}$, p.o.). One hour after oral administration of normal saline or extract in Groups I \& II, and $30 \mathrm{~min}$ after oral ingestion of MSAD in Group III, mice were subjected to TST [7].

Involvement of Muscarinic Cholinergic Receptor Pathway

Mice were randomly divided into 3 groups, containing 5 mice per group $(n=5)$. Group I: mice received normal saline p.o $(10 \mathrm{~mL} / \mathrm{kg})$; Groups II: mice received $200 \mathrm{mg} / \mathrm{kg}$, p.o of MSAD; Group III: mice were pretreated with atropine $(1 \mathrm{mg} / \mathrm{kg}$, i.p., a muscarinic cholinergic receptor antagonist), 15 minutes before the orogastric ingestion of MSAD (200 $\mathrm{mg} / \mathrm{kg}$, p.o.). One hour after oral administration of normal saline or extract in Groups I \& II, and $45 \mathrm{~min}$ after oral ingestion of MSAD in Group III, mice were subjected to TST [35].

Involvement of N-Methyl-D-aspartate (NMDA) Receptor Pathway

Mice were randomly divided into 3 groups, containing 5 mice per group $(\mathrm{n}=5)$. Group I: mice received normal saline p.o (10 mL/kg); Groups II: mice received $200 \mathrm{mg} / \mathrm{kg}$, p.o of MSAD; Group III: mice were pretreated with ascorbic acid $(100 \mathrm{mg} / \mathrm{kg}$, i.p., a putative neuromodulator that antagonizes NMDA receptors) $30 \mathrm{~min}$ before oral administration of MSAD (200 mg/kg, p.o.). One hour after oral administration of normal saline or extract in Groups I \& II, and 30 min after oral ingestion of MSAD in Group III, mice were subjected to TST [36].

Involvement of Gabaergic Pathway

Mice were randomly divided into 3 groups, containing 5 mice per group $(n=5)$. Group I: mice received normal saline p.o (10 mL/kg); Groups II: mice received $200 \mathrm{mg} / \mathrm{kg}$, p.o of MSAD; Group III: mice were pretreated with baclofen $\left(10 \mathrm{mg} / \mathrm{kg}\right.$, i.p., $\mathrm{GABA}_{\mathrm{B}}$ agonist) 15 minutes before the oral administration of MSAD (200 mg/kg, p.o.). One hour after oral administration of normal saline or extract in Groups I \& II, and 45 min after oral ingestion of MSAD in Group III, mice were subjected to TST [6].

Involvement of L-Arginine-NO-cGMP Pathway

Mice were randomly divided into 5 groups, containing 5 mice per group $(\mathrm{n}=5)$. Group I: mice received normal saline p.o (10 mL/kg); Groups II: mice received $200 \mathrm{mg} / \mathrm{kg}$, p.o of MSAD; Group III \& IV mice were pretreated with LArginine $[750 \mathrm{mg} / \mathrm{kg}$, i.p., a precursor of nitric oxide (NO)] and methylene blue $[10 \mathrm{mg} / \mathrm{kg}$, i.p., an inhibitor of nitric oxide synthase and an inhibitor of soluble guanylate cyclase (sGC)] respectively $15 \mathrm{~min}$ before MSAD; Group $\mathrm{V}$ : mice orally treated with MSAD, 30 min before L-NNA $(0.3 \mathrm{mg} / \mathrm{kg}$, i.p., a competitive inhibitor of NO synthase with selectivity for the neuronal and endothelial isoforms of the enzyme). One hour after oral administration of normal saline or extract in Groups I \& II, 45 min after MSAD ingestion in Group III \& IV [37] and 30 min after MSAD administration in Group V, mice were tested on TST [38].

\subsection{Statistical Analysis}

Results were expressed as mean \pm S.E.M. The significance of the difference between treated groups and the negative group were analyzed using one-way analysis of variance (ANOVA), followed by Dunnett's post hoc analysis. The level of significance for all tests was set at $p<$ 0.05 compared to the negative control group.

\section{Results}

\subsection{Result of $\mathbf{L D}_{50}$ Determination}

The $\mathrm{LD}_{50}$ of MSAD was found to be $>5000 \mathrm{mg} / \mathrm{kg}$, p.o. in mice.

\subsection{Effect of MSAD on Tail Suspension Test (TST) in Mice}

The effect of MSAD (200 - $800 \mathrm{mg} / \mathrm{kg}$, p.o.) on TST is shown in Figure 1. MSAD at 200, 400 and $800 \mathrm{mg} / \mathrm{kg}$

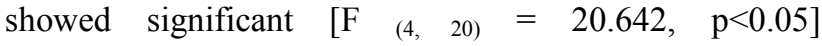
dose-dependent decrease in anti-immobility time when compared to the vehicle-treated control group. MSAD at all the doses used also shortened the immobility time more than the positive control drug fluoxetine. 


\subsection{Effect of Various Receptor Antagonists on the Antidepressant Effect of MSAD on TST in Mice}

The results obtained for the effects of various antagonists on the antidepressant-like activity of MSAD are presented in Figure 2A-H. Pretreatment with prazosin $(62.5 \mu \mathrm{g} / \mathrm{kg})$, yohimbine, $(1 \mathrm{mg} / \mathrm{kg})$, sulpiride $(50 \mathrm{mg} / \mathrm{kg})$, L- arginine $(750 \mathrm{mg} / \mathrm{kg})$, methylene blue $(10 \mathrm{mg} / \mathrm{kg}$, ) and baclofen $(10 \mathrm{mg} / \mathrm{kg})$, significantly $\left[\mathrm{p}<0.05, \mathrm{~F}_{(2,12)}=17.714\right.$, $12.721,18.073,20.776,11.056$ and 35.798] reversed the antidepressant-like effect of MSAD (200 mg/kg, p.o.) respectively. Propranalol $(2 \mathrm{mg} / \mathrm{kg})$, atropine $(1 \mathrm{mg} / \mathrm{kg})$ cyproheptadine $(3 \mathrm{mg} / \mathrm{kg})$, L- nitroarginine $(10 \mathrm{mg} / \mathrm{kg})$, and ascorbic acid $(100 \mathrm{mg} / \mathrm{kg})$, did not reverse the antidepressant effect of MSAD in TST.

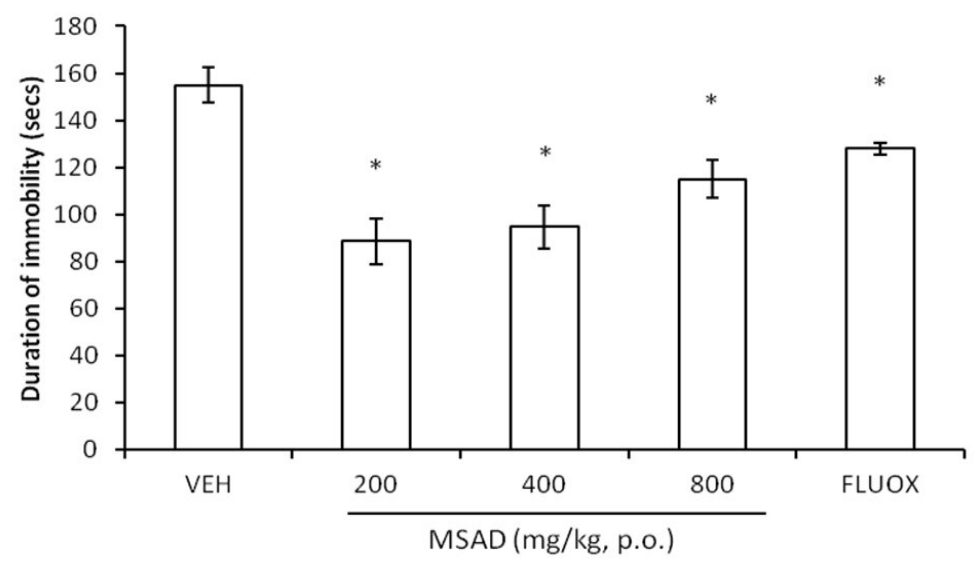

Figure 1. Antidepressant effect of methanol stem bark extract of Adansonia digitata on TST test in mice. VEH; Vehicle (10 mL $/ \mathrm{kg}$, normal saline), MSAD; Methanol stem bark extract of Adansonia digitata, FLUOX; fluoxetine $(20 \mathrm{mg} / \mathrm{kg})$. Each bar represents Mean $\pm \mathrm{SEM}, \mathrm{n}=5$. *p $<0.05$ compared to the vehicle $\left[\mathrm{F}_{(4,20)}=11.438, \mathrm{p}<0.0001\right]$ (ANOVA, Student-Newman-Keuls post hoc test).

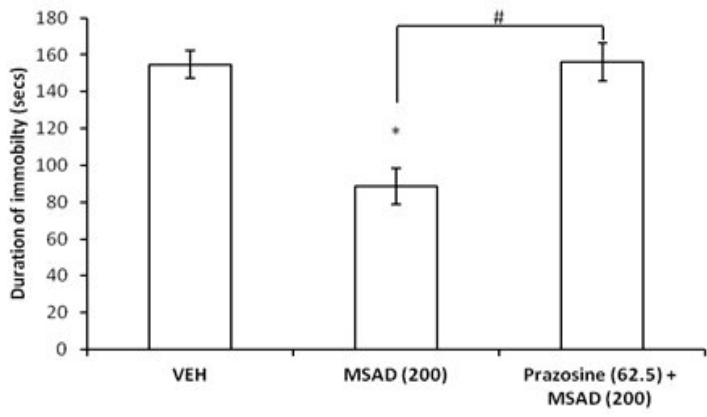

A

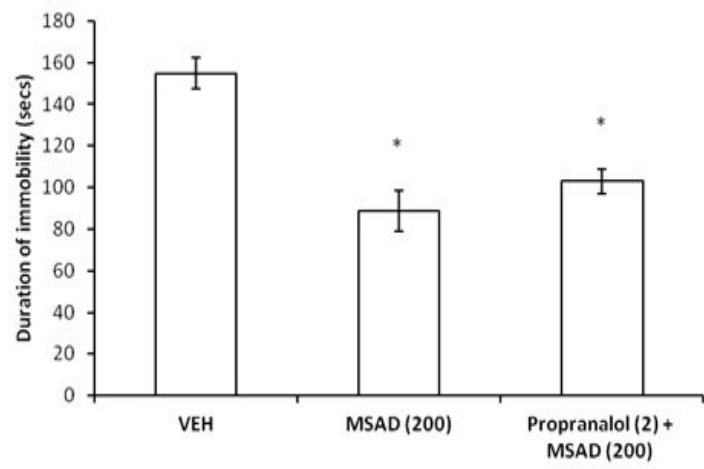

C

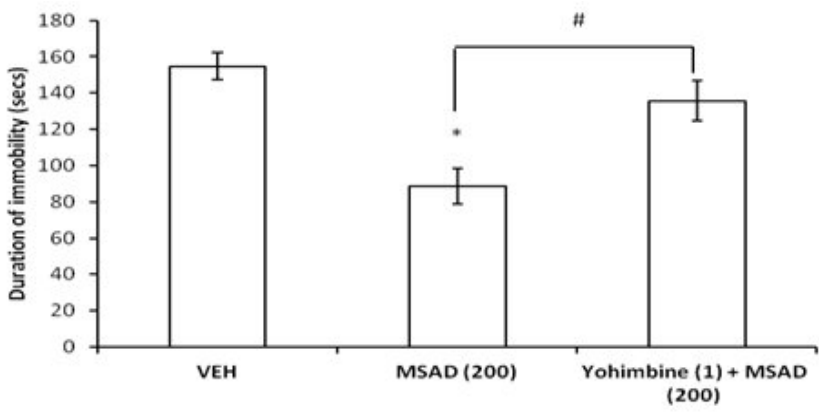

B

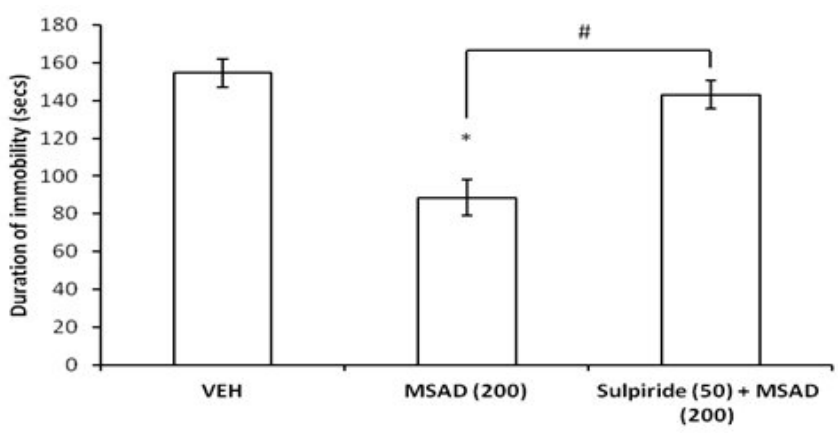

D 


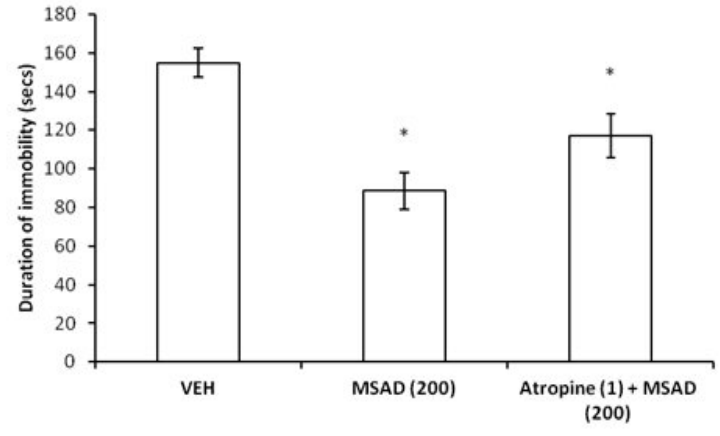

$\mathbf{E}$

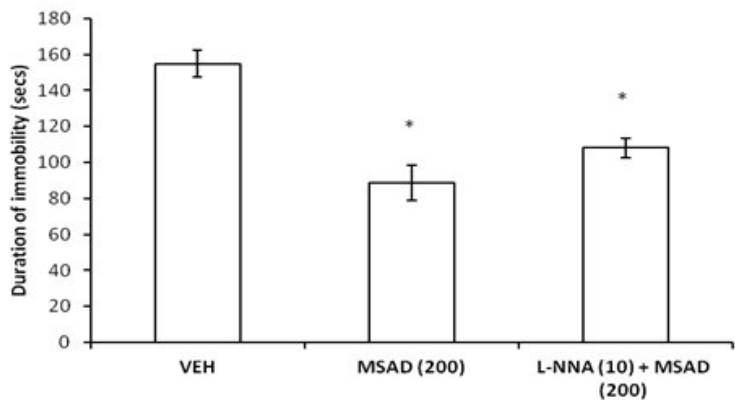

G

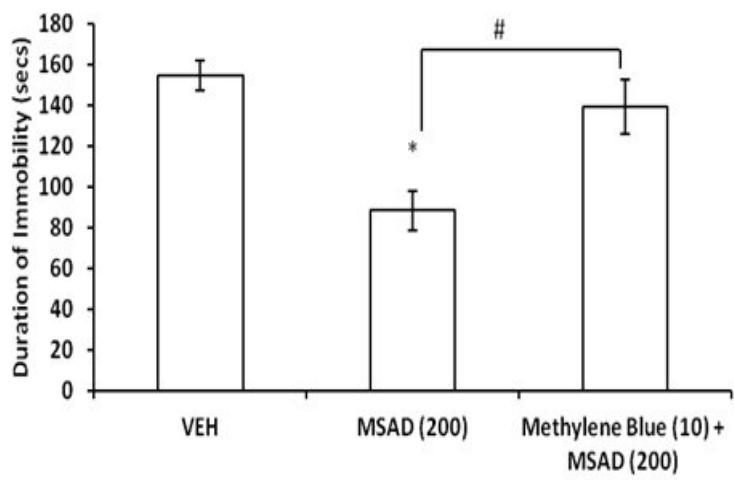

I

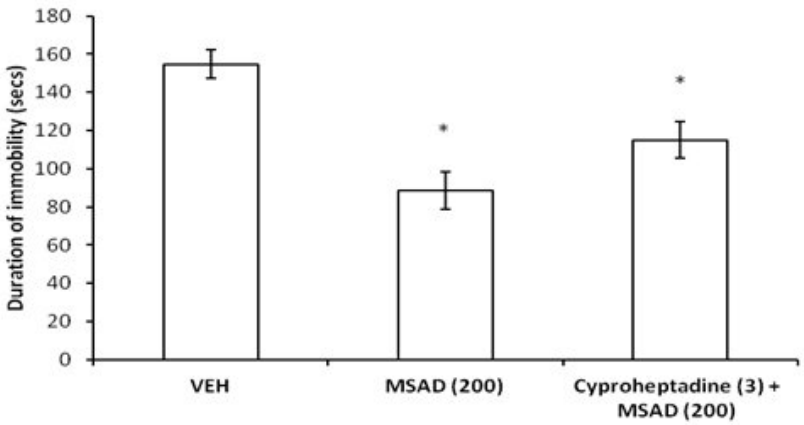

F

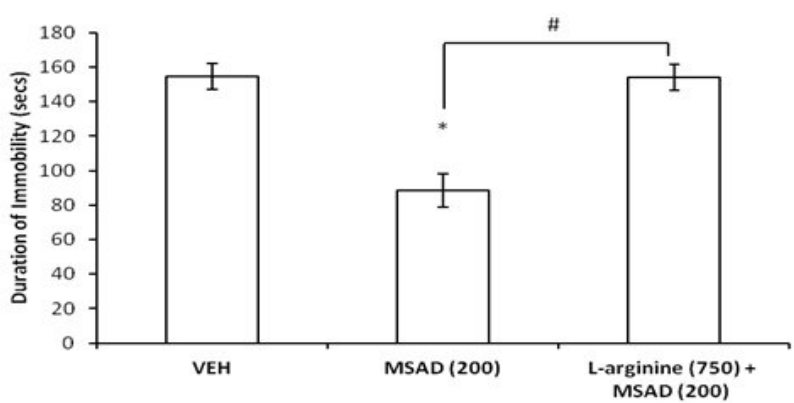

H

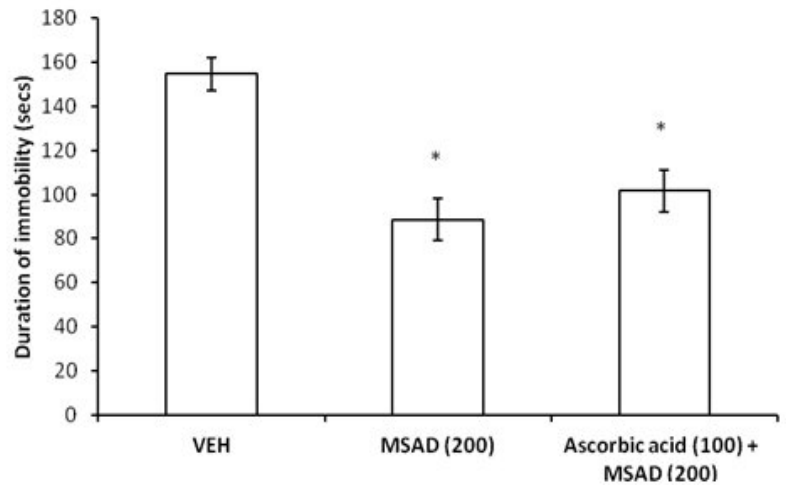

$\mathbf{J}$

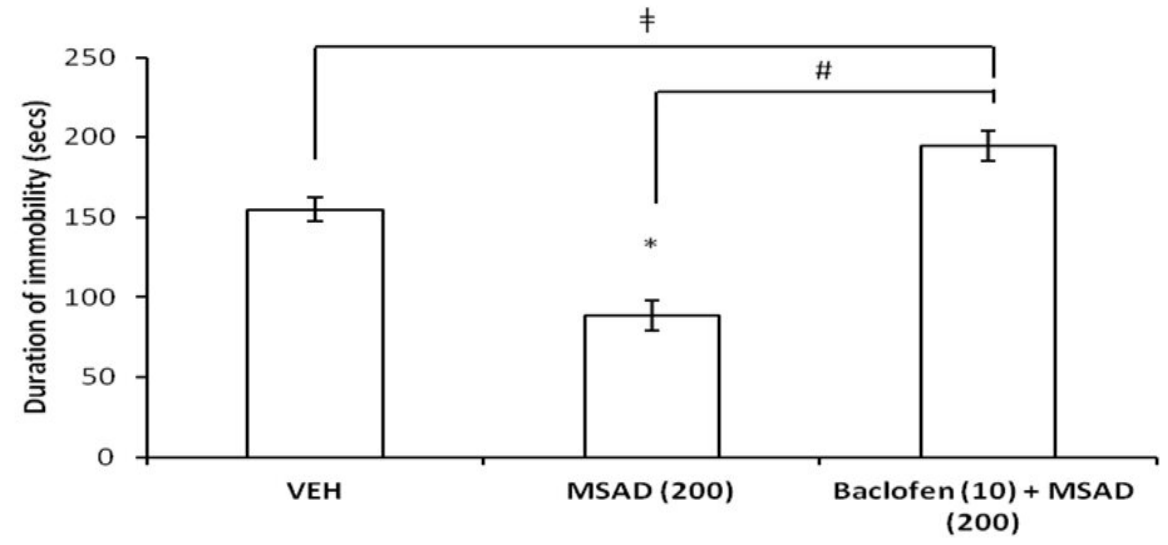

K

Figure 2. A-K: The effects of various antagonists, agonist, inhibitor and precursor: A (prazosin), B (yohimbine), C (propranolol), D (sulpiride), E (atropine), F (cyproheptadine), G (L-nitroarginine), H (L-arginine), I (methylene blue), J (ascorbic acid) and K (baclofen) on the anti-immobility activity of MSAD in TST. 
Table 1. Effects of MSAD on locomotor and rearing behaviours in mice in the open field

\begin{tabular}{|c|c|c|c|c|}
\hline \multirow[t]{2}{*}{ Group } & \multirow[t]{2}{*}{ Dose $(\mathrm{mg} / \mathrm{kg})$} & Number of square crossed & Number of rearing & Total activities \\
\hline & & \multicolumn{3}{|c|}{ Mean \pm S.E.M } \\
\hline Vehicle & $(10 \mathrm{~mL} / \mathrm{kg})$ & $68.8 \pm 5.0$ & $27.0 \pm 1.9$ & $95.8 \pm 5.9$ \\
\hline MSAD & 100 & $73.2 \pm 2.3$ & $26.8 \pm 1.9$ & $100.0 \pm 2.7$ \\
\hline MSAD & 200 & $69.6 \pm 3.6$ & $26.2 \pm 1.9$ & $92.8 \pm 6.0$ \\
\hline MSAD & 400 & $74.0 \pm 4.6$ & $26.0 \pm 1.7$ & $100.2 \pm 6.2$ \\
\hline DZP & 1 & $85.4 \pm 6.2$ & $13.6 \pm 2.5^{*}$ & $99.0 \pm 7.8$ \\
\hline
\end{tabular}

MSAD; methanol stem bark extract of Adansonia digitata, DZP; diazepam. Each value represents Mean $\pm \mathrm{SEM}, \mathrm{n}=5 .{ }^{*} \mathrm{p}<0.05$ compared to the vehicle. (ANOVA, Dunnett's post hoc test)

\subsection{Effect of MSAD on Locomotor Behaviour in Open Field (OFT) Test in Mice}

MSAD at 200, 400 and $800 \mathrm{mg} / \mathrm{kg}$, per oral, did not show any significant effects on locomotor activity in mice. Although, there was a dose-dependent decrease in rearing but not significant from the vehicle-treated control group as assessed from the OFT (Table 1). However, the standard sedative drug, diazepam $(1 \mathrm{mg} / \mathrm{kg})$ significantly $\left[\mathrm{F}_{(4,20)}=\right.$ $8.516, \mathrm{p}=0.004]$ reduced rearing in mice compared to the vehicle-treated control group. The result is presented in Table 1.

\section{Discussion}

This study examined the acute toxicity $\left(\mathrm{LD}_{50}\right)$ and mechanism of antidepressant-like effect of methanol stem bark extract of Adansonia digitata (MSAD) using various receptor antagonists in tail suspension (TST) behavioural test in mice. The results obtained revealed that MSAD may not be toxic and possessed antidepressant-like activity in TST acting via multiple receptor neurotransmission.

The acute toxicity $\left(\mathrm{LD}_{50}\right)$ study of MSAD was greater or equal to $5000 \mathrm{mg} / \mathrm{kg}$ suggesting that MSAD may not be toxic to mice. Since, according to Hayes, no toxicity could be considered above $5 \mathrm{~g} / \mathrm{kg}$ [39]. Therefore, low oral doses of 200,400 and $800 \mathrm{mg} / \mathrm{kg}$, per oral of MSAD were chosen for this study, since antidepressant drugs are expected to be used for a long period of time [40].

In addition, the doses of MSAD used in this study, were also selected, such that, they did not significantly, alter the spontaneous locomotor activity of mice using an open field test (Table 1), thereby ruling out the possibility of getting a false positive result in the antidepressant effects of MSAD and as such, the observed antidepressant effect of MSAD may not be due to psychostimulant effect which decreases immobility time by stimulating locomotor activity $[41,42$, 43].

The TST presents some advantages over FST in that it allows an objective measure of immobility, by avoiding hypothermia, induced by immersion in water. In addition, TST is strongly correlated with antidepressant effects in humans, and can be used to distinguish between antidepressants and other psychotropic drugs, such as antipsychotics, and anxiolytics [44], thus, TST was chosen for the delineation of the probable neural mechanism of MSAD [45] in this study.

MSAD shortened immobility time in TST suggesting an antidepressant-like effect. This finding is in line with previous findings of agents that shortened immobility time in TST, which were suggested to have antidepressant-like effect in TST [37, 46]. Of particular interest, is the dose-dependent increase in antidepressant effect of MSAD reported by earlier researchers [47] with highest antidepressant effect exhibited at $1000 \mathrm{mg} / \mathrm{kg}$, per oral in their study, but in our study, the lowest tested dose of 200 $\mathrm{mg} / \mathrm{kg}$, per oral of MSAD showed the highest antidepressant effect.

The reason for this pattern of result could be the different methods of the plant extraction protocol employed. For example, Shehu et al. [47] used a soxhlet extraction protocol, while we used a cold maceration method using the same solvent. It could probably be suggested, that Adansonia digitata stem bark may contain thermolabile constituents, thereby making cold maceration a better alternative to soxhlet extraction, since cold maceration is best used in case of thermolabile drugs [48]. This suggestion may be supported with earlier reports, that prolong heating using soxhlet extraction protocol, may lead to the degradation of compounds, and not suitable for thermolabile compounds $[49,50,51]$. However, cold maceration techniques may be a better technique of preparing such medicinal plant extract [48]. Subsequently, our finding may probably favour the long use of the plant extract at $200 \mathrm{mg} / \mathrm{kg}$, compared to $1000 \mathrm{mg} / \mathrm{kg}$ in the previous study, as antidepressant drugs are normally ingested over a long period of time [40].

Of all the tested doses of 200,400 and $800 \mathrm{mg} / \mathrm{kg}$ of MSAD in this study, $200 \mathrm{mg} / \mathrm{kg}$ showed to be most effective at reducing immobility in TST, therefore, 200 $\mathrm{mg} / \mathrm{kg}$ was selected for the delineation of the mechanism of 
antidepressant-like effect of MSAD in TST.

Previous reports have indicated that acute administration of $\alpha_{1}$ - adrenergic receptor antagonist and $\alpha_{2}$ - adrenergic receptor antagonists abolished the antidepressant effect of antidepressant agents in TST $[37,46]$. In this study, the anti-immobility effect of MSAD was abolished by prasozin (an $\alpha_{1}$-adrenoceptor antagonist) (Figure 2 Panel A) and yohimbine (an $\alpha_{2}$-adrenoceptor antagonist) (Figure 2 Panel B) suggesting that MSAD might be acting via interaction with $\alpha_{1}$ - and $\alpha_{2}$-adrenoceptors. This observation is in line with previous reports of medicinal plants acting via these mechanisms $[37,46]$.

Antagonism of dopaminergic receptor pathway has been demonstrated to reverse antidepressant effect of medicinal agents, acting via dopaminergic neurotransmission in TST $[38,46]$. The reversal of the antidepressant-like effect of MSAD by sulpiride (Figure 2 Panel D) suggests that MSAD may be acting via agonistic action on a dopaminergic neuronal pathway to exert its antidepressant-like effect. This experimental finding is in line with earlier experimental findings of the medicinal agents whose antidepressant-like effects were reversed by sulpiride and suggested to be acting via dopaminergic pathways $[38,46]$.

Inhibition of 5- $\mathrm{HT}_{2}$ receptors plays an important role in the antidepressant effect of the antidepressant agent in TST [37]. In this study, pretreatment of mice with cyproheptadine (a 5- $\mathrm{HT}_{2}$ receptor antagonist), did not reverse the antidepressant-like effect of MSAD, indicating that its antidepressant-like effect, may not be mediated via $5-\mathrm{HT}_{2}$ receptor neurotransmissions.

In this study, pretreatment of mice with baclofen reversed the antidepressant-like effect of MSAD (Figure 2 Panel K) suggesting that $\mathrm{GABA}_{\mathrm{B}}$ receptor neurotransmission may be involved in the antidepressant effect of MSAD in TST. Previous studies have shown that antidepressant-like effects of medicinal plant extracts were abolished by baclofen $\left(\mathrm{a} \mathrm{GABA}_{\mathrm{B}}\right.$ receptor agonist) in TST suggesting the involvement of $\mathrm{GABA}_{B}$ receptor in the antidepressant-like effect of these extracts $[52,53]$ since $\mathrm{GABA}_{\mathrm{B}}$ receptor antagonism may serve as a basis for the generation of novel antidepressants [54]. This study is in conformity with earlier reports of the involvement of $\mathrm{GABA}_{\mathrm{B}}$ receptor neurotransmission in the antidepressant effect of medicinal plants $[52,53]$.

Pretreatment of mice with propranolol (a $\beta$ adrenergic receptor antagonist), atropine (a muscarinic cholinergic receptor antagonist) and ascorbic acid (a putative neuromodulator at the NMDA receptor) did not reverse the antidepressant effect of MSAD suggesting that the observed antidepressant effect of MSAD may not be mediated via $\beta$ adrenergic, muscarinic cholinergic and glutaminergic via NMDA receptor pathways.

Numerous studies have ascribed an important role to the L-arginine-NO-cGMP pathway in the pathophysiology of depression $[8,55]$. In this study, pretreatment with
L-arginine reversed the antidepressant effect of MSAD (Figure 2 Panel $\mathrm{H}$ ) which is consistent with an earlier report [56]. However, L-NNA did not reverse or potentiate the antidepressant effect of MSAD rather pretreatment with L-NNA before the administration of MSAD showed antidepressant effect; this observation could be supported with earlier finding that nitric oxide inhibitors exert antidepressant-like effects in animal models predictive of antidepressant activity $[57,58]$.

\section{Conclusions}

This study concluded that MSAD may possess antidepressant effect, and its probable neural mechanism of action may involve multiple receptor pathways.

\section{REFERENCES}

[1] World Health Organisation. The World health report 2001: Mental health: new understanding, new hope. Geneva; 2001.

[2] R.C Kessler, P Berglund, O Demler, R Jin, D Koretz, K. R Merikangas et al. National comorbidity survey replication, the epidemiology of major depressive disorder: results from the national comorbidity survey replication (NCS-R). J. Am Med Assoc, 289: 3095-3105; 2003.

[3] J.P Lepine, M Briley. The increasing burden of depression. Neuropsychiatr Dis Treat, 7:3-7; 2011.

[4] I Hindmarch. Beyond the monoamine hypothesis: mechanisms, molecules and methods. Eur Psychiatry, 17(3): 294-299; 2002.

[5] S.K Kulkarni, MK Bhutani, M. Bishnoi. Antidepressant activity of curcumin: involvement of serotonin and dopamine system. Psychopharmacology, 201(3): 435-442; 2008.

[6] D Dhingra, V Kumar. Evidences for the involvement of monoaminergic and GABAergic systems in antidepressant-like activity of garlic extract in mice. Indian J Pharmacol, 40(4): 175-179; 2008.

[7] F Donato, M.G Gomes, A.T RossitoGoes, N Seus, D Alves, C.R Jesse et al. Involvement of the dopaminergic and serotonergic systems in the antidepressant-like effect caused by 4-phenyl-1-(phenylselanylmethyl)-1, 2, 3-triazole. Life Sci, 93(9-11): 393-400; 2013.

[8] A Dhir, SK Kulkarni. Involvement of nitric oxide (NO) signaling pathway in the antidepressant action of bupropion, a dopamine reuptake inhibitor, Eur $\mathrm{J}$ of Pharmacol, 568(1-3):177-85; 2007.

[9] A.O Rosa, I. Lin, J.B Calixto, A.R.S Santos, A.L.S Rodrigues. Involvement of NMDA receptors and L-arginine-nitric oxide pathway in the antidepressant-like effects of zinc in mice. Behav Brain Res, 144(1-2):87-93; 2003.

[10] Z.F Yu, L.D Kong, Y Chen. Antidepressant activity of 
aqueous extracts of Curcuma longa in mice: Ethnopharmocol, 83: 161; 2002.

[11] D. Antai-Otong. Antidepressant-induced insomnia: Treatment options. Perspect Psych Care, 40:29-33; 2004.

[12] D Baldwin, K Bridgman, C Buis. Resolution of sexual dysfunction during double-blind treatment of major depression with reboxetine or paroxetine. J Psychopharmacol, 20:91-6; 2006.

[13] R.N Khurana, T.E Baudendistel. Hypertensive crisis associated with venlafaxine. Am J Med, 115:676-7; 2003.

[14] W Jintanaporn, P Prasert, S Kittisak, M Supaporn, S Bungorn. Evaluation of the anxiolytic and antidepressant effects of alcoholic extract of Kaempferia parviflora in aged rats. Am J Agri Bio Sci, 2: 94-98; 2007.

[15] G Calapai, A.P Caputi. Herbal medicines: can we do without pharmacologist? Evid-based Complementary and Altern Med, 4(1): 41-43; 2007.

[16] J.Y Guo, C.C Han, Y.M Liu. A contemporary treatment approach to both diabetes and depression by Cordyceps sinensis, Rich in Vanadium. Evid-based Complementary and Altern Med, 7(3): 387-389; 2010.

[17] N. Ito, T. Nagai, T. Oikawa, H. Yamada, and T. Hanawa. Antidepressant-like Effect of 1-perillaldehyde in Stress-induced Depression-like Model Mice through Regulation of the Olfactory Nervous System. Evid-Based Complementary and Altern Med, vol. 2011, Article ID 512697, 5 pages, 2011.

[18] G.P.P Kamatou, I Vermaak, A.M Viljoen. An updated review of Adansonia digitata: A commercially important African tree. S Afr J Bot, 77:908-919; 2011.

[19] G.E Wickens, P Lowe. The baobabs: pachycauls of Africa. Madagascar and Australia, Springer, UK, 2008.

[20] P Kinda, P Zerbo, S Guenné, M Compaoré, a Ciobica, M Kiendrebeogo. Medicinal Plants Used for Neuropsychiatric Disorders Treatment in the Hauts Bassins Region of Burkina Faso. Medicines, 4(2):32; 2017.

[21] A Shehu, M.G Magaji, J. Yau, A Abubakar. Ethnobotanical survey of medicinal plants used for the management of depression by Hausa tribes of Kaduna state, Nigeria. J Med Plants Res, 11(36):562-567; 2017.

[22] K Inngjerdingen, C.S Nergård, D Diallo, P.P Mounkoro, B.S Paulsen. An ethnopharmacological survey of plants used for wound healing in Dogonland, Mali, West Africa. J Ethnopharmacol, 92: 233-244; 2004.

[23] E.M El-Rawy, S.M Gergis, S Bazaid, S.A El-Mougy. The immunostimulant effect of Adansonia digitata on the immune response of chicken vaccinated with avian cholera vaccine. Journ. Egypt. Veterinary Med Asso, 57:959-970; 1997.

[24] A Ramadan, F.M Harraz, S.A El-Mougy. Anti-inflammatory, analgesic and antipyretic effects of the fruit pulp of Adansonia digitata. Fitoterapia, 15: 418-422; 1994.

[25] K Ananil, J.B Hudson, C De Souzal, K Akpaganal, G.H.N Tower, J.T Amason et al. Investigation of medicinal plants of Togo for antiviral and antimicrobial activities. Pharm Biol, $38: 40-45 ; 2000$
[26] A Lamien-Meda, C.E Lamien, M.M.Y Compaoré, R.N.T Meda, M Kiendrebeogo,B Zeba et al. Polyphenol content and antioxidant activity of fourteen wild edible fruits from Burkina Faso. Molecules, 13:581-594; 2008.

[27] A.A Al-Qarawi, M.A Al-Damegh, S.A El-Mougy. Hepatoprotective influence of Adansonia digitata pulp. J Herbs Spices Med Plants, 10: 1-6; 2003.

[28] M.S Abbasi, R Bekhradi, J Asgharpanah, M.F Abbasi, A Maleki. Antidepressant effect of aqueous and hydroalcoholic extracts of Lavandula officinalis in forced swim test and tail suspension test in male mice. J Arak Univ Med Sci. 2013; 16: 65-75; 2013.

[29] M Hamon, P Blier. Monoamine neurocircuitry in depression and strategies for new treatments. Prog Neuropsychopharmacol Biol Psychiatry, 45:54-63; 2013.

[30] S.B Khushboo. Antidepressants: mechanism of action, toxicity and possible amelioration. J Appl Biotechnol Bioeng, 3(5):437-448, 2017.

[31] W. Waldegrave. Council Directive 86/609/EEC of 24 November 1986 on the approximation of laws, regulations and administrative provisions of the member states regarding the protection of animals used for experimental and other scientific purposes. Pg1-46.

[32] OECD. Guidelines for Testing of Chemicals: Guideline 425: Acute Oral Toxicity. Paris, France. The Organization of Economic Co-operation and Development, 2008.

[33] V.H Potdar, S.K Kibile. Evaluation of Antidepressant-like Effect of Citrus maxima Leaves in Animal Models of Depression. Iran J Basic Med Sci, 14(5):478-483; 2011.

[34] S Abbasi-Maleki, Z Mousavi. Hydroethanolic extract of Carthamus tinctorius induces antidepressant-like effects: modulation by dopaminergic and serotonergic systems in tail suspension test in mice. Iran J Basic Med Sci, 20:1063-1073; 2017.

[35] S.A Onasanwo, K.O Ilenre, S.O Faborode. The Impact of Kolaviron (A Bioflavonoid of Garcinia Kola Seed) On Depression Status in Laboratory Rodents: Roles of Monoaminergic Systems. Ann Depress Anxiety, 2(1): 1042; 2015 .

[36] M Mantovani, R Pertile, J.B Calixto, A.R.S Santos, A.L.S Rodrigues. Melatonin exerts an antidepressant-like effect in the tail suspension test in mice: evidence for involvement of $\mathrm{N}$-methyl-D-aspartate receptors and the L-arginine-nitric oxide pathway. Neurosci Lett, 343: 1-4; 2003.

[37] D.W Adongo, K.K.E Kukuia, P.K Mante, E.O Ameyaw, E. Woode. Antidepressant-Like Effect of the Leaves of Pseudospondias microcarpa in Mice: Evidence for the Involvement of the Serotoninergic System, NMDA Receptor Complex, and Nitric Oxide Pathway. Biomed Res Int, 397943; 2015.

[38] A.L.B Zeni, A.D.E Zomkowski, T Dal-Cim, M Maraschin, A.L.S Rodrigues, C.L Tasca. Antidepressant-like and neuroprotective effects of Aloysia gratissima: Investigation of involvement of 1-arginine-nitric oxide-cyclic guanosine monophosphate pathway. J Ethnopharmacol, 137(1): 864-874; 2011.

[39] A.W Hayes. Guidelines for acute oral toxicity testings. In: 
Principles and Methods of Toxicity, 2nd Edn. Raven Press Ltd., New York. (Table 4):185; 1989.

[40] L.A Akinpelu, T.A Adegbuyi, S.S Agboola, Olaonipekun J.K, Olawuni I.J, Adegoke A.M, Oyemitan I.A et al. Antidepressant Activity and Mechanism of Aqueous Extract of Vigna Unguiculata ssp. Dekindtiana (L.) Walp Dried Aerial Part in Mice. Int. J Neurosci Behav Sci, 5: 7-18; 2017.

[41] M Bourin, A.J Fiocco, F Clenet. How valuable are animal models in defining antidepressant activity. Human Psychopharmacology, 16(1): 9-21; 2001.

[42] M.P Kaster, P.K Ferreira, A.R Santos, A.L Rodrigues. Effects of potassium channel inhibitors in the forced swimming test: possible involvement of L-arginine-nitric oxide-soluble guanylate cyclase pathway. Behav Brain Res, 165(2):204-9; 2005

[43] A.D.E Zomkowski, A.R.S Santos, A.L.S Rodrigues. Putrescine produces antidepressant-like effects in the forced swimming test and in the tail suspension test in mice. Prog Neuro-Psychopharmacol Biol Psychiatry, 30(8): 1419-1425; 2006.

[44] J.F Cryan, C Mombereau, A Vassout. The tail suspension test as a model for assessing antidepressant activity: review of pharmacological and genetic studies in mice. Neurosci Biobehav Rev, 29(4-5): 571-625; 2005.

[45] N Ripoll, D.J.P David, E Dailly, M Hascoët, M Bourin. Antidepressant-like effects in various mice strains in the tail suspension test. Behav Brain Res, 143(2): 193-200; 2003.

[46] D Dhingra, R Valecha. Evaluation of antidepressant-like activity of aqueous and ethanolic extracts of Terminalia bellirica Roxb. fruits in mice. Indian J Exper Biol, 45: 610-616; 2007.

[47] A Shehu, M.G Magaji, J Yau, B Mahmud, A Ahmed. Antidepressant Effect of Methanol Stem Bark Extract of Adansonia digitata L. (Malvaceae) in Mice. Trop J Nat Prod Res. 2(2): 87-91; 2018

[48] N.S Ncube, A.J Afolayan, A.I Okoh. Assessment techniques of antimicrobial properties of natural compounds of plant origin: current methods and future trends. Afr J Biotechnol, 27 (12): 1797-1806; 2008.
[49] S.R De Paiva, M.A.C Kaplan, O.R Gottlieb. Systematic positioning of Plumbaginaceae. An Acad Bras Cienc, 67: 461-466; 1995

[50] K Das, R.K.S Tiwari, D.K Shrivastava. Techniques for evaluation of medicinal plant products as antimicrobial agent: Current methods and future trends. Journal of Medicinal Plants Research, 4(2): 104-111; 2010.

[51] S.B Nikhal, P.A Dambe, D.B Ghongade, D.C Goupale. Hydroalcoholic extraction of Mangifera indica (leaves) by Soxhletion. Int J Pharm Sci, 2 (1): 30-32; 2010.

[52] D Dhingra, P.K Goyal. Evidences for the involvement of monoaminergic and GABAergic systems in antidepressant-like activity of Tinospora cordifolia in mice. Indian J Pharm Sci, 70 (6): 761-767; 2008.

[53] M Parle, G Pooja. Eat pineapple a day to keep depression at bay. Int J Res Ayurveda Pharm, 1(2): 439-448; 2010.

[54] C Mombereau, K Kaupmann, W Froestl, G Sansig, H van der Putten, J.F Cryan. Genetic and pharmacological evidence of a role for $\mathrm{GABA}{ }_{\mathrm{B}}$ ) receptors in the modulation of anxiety and antidepressant-like behavior. Neuropsychopharmacol, 29:1050-62; 2004.

[55] M Ghasemi, H Sadeghipour, G Poorheidari, A.R Dehpour. A role for nitrergic system in the antidepressant-like effects of chronic lithium treatment in the mouse forced swimming test. Behav Brain Res, 200(1): 76-82; 009.

[56] A Dhir, S.K Kulkarni. Possible involvement of nitric oxide (NO) signaling pathway in the antidepressant-like effect of MK-801 (dizocilpine) a NMDA receptor antagonist in mouse forced swim test. Indian J Exper Biol, 46(3): 164-70; 2008.

[57] I.L Heiberg, G Wegener, R Rosenberg. Reduction of cGMP and nitric oxide has antidepressant-like effects in the forced swimming test in rats. Behav Brain Res, 134(1-2): 479-484; 2002 .

[58] O Mutlu, G Ulak, a Laugeray, C Belzung. Effects of neuronal and inducible NOS inhibitor 1-[2-(trifluoromethyl) phenyl] imidazole (TRIM) in unpredictable chronic mild stress procedure in mice. Pharmacol Biochem Behav, 92(1): 82-87; 2009. 